\section{Stem Anatomy and Grafting Success of Chinese Chestnut Scions on 'AU-Cropper' and 'Qing' Seedling Rootstocks}

\author{
Michele R. Warmund ${ }^{1}$ \\ Division of Plant Sciences, University of Missouri, 1-31 Agriculture Building, \\ Department of Horticulture, Columbia, MO 65211 \\ Billy G. Cumbie \\ Division of Biological Sciences, University of Missouri, Columbia, MO 65211
}

\author{
Mark V. Coggeshall \\ Center for Agroforestry, University of Missouri, Columbia, MO 65211
}

Additional index words. Castanea mollissima, graft union, moisture content, incompatibility, phloem fibers, propagation

\begin{abstract}
Grafting failure of Chinese chestnut (Castanea mollissima Blume) trees is common. Some researchers have suggested that secondary phloem fibers in chestnut rootstock stems may interfere with graft union formation. Others suggest that high rootstock moisture content may reduce grafting success. This study was conducted to ascertain the precise arrangement of secondary phloem fibers in Chinese chestnut seedling rootstocks and to determine if they are associated with grafting failure. We also investigated the effects of moisture content of rootstocks and container growing medium on grafting success. Nodes on Chinese chestnut seedlings had 2/5 phyllotaxy with five alternate buds present in two revolutions around the stem. Vascular cambium in 1-yearold rootstock stems was arranged in a regular five-lobed cylinder in cross-sections. Primary phloem fibers were present in a discontinuous ring and secondary phloem fibers were usually clustered outside the cambium between the lobes. Grafts were successful when scion buds were placed on the rootstock disrupting secondary phloem fibers with cambia of the budded tissues aligned. Containerized rootstocks at $56 \%$ and $62 \%$ growing medium moisture content before grafting had $25 \%$ graft union success rates, whereas non-irrigated plants at $\mathbf{4 8 \%}$ moisture had a $\mathbf{7 5 \%}$ success rate.
\end{abstract}

Many techniques have been used to propagate chestnut trees in Europe, including chip, patch, and t-budding as well as whip and tongue, cleft, and side veneer grafting (Balta et al., 1993; Bazzigher et al., 1984; PereiraLorenzo and Fernanez-Lopez, 1997; Serdar and Soylu, 2005). In the United States, commercial nurseries generally use chip-budding or whip and tongue grafting to propagate Chinese chestnut (Castanea mollissima) trees (W. Lovelace, personal communication), whereas small chestnut producers often use the three-flap method on field-planted seedling rootstock, which is grafted 1 year after establishment (Hunt et al., 2009; Reid, 2010).

Regardless of the technique used, the grafting success rate is often low with chestnut and has limited the availability of trees for commercial production in the United States (Warmund, 2011; Weber and MacDaniels, 1969). Early researchers speculated that graft

Received for publication 22 Mar. 2012. Accepted for publication 27 Apr. 2012.

Contribution from the Missouri Agricultural Station project 322

${ }^{1}$ To whom reprint requests should be addressed; e-mailwarmundm@missouri.edu. failure was caused by scion/rootstock incompatibility with restricted flow of nutrients through the union (MacDaniels, 1955; Weber and MacDaniels, 1969). Alternatively, it was hypothesized that low winter temperatures injured the developing tissues in the graft union (MacDaniels, 1955). Others suggested that poor grafting technique or chestnut blight infection caused union failure, especially when using different scion and rootstock species (McKay and Jaynes, 1969). Chipbudding 'AU-Super' scions onto 'AU-Cropper' seedling rootstocks in late summer also resulted in lower grafting success than budding in midSeptember (Warmund and Coggeshall, 2009).

Excessive sap flow or stem bleeding caused by strong root pressure is problematic when field-grafting chestnut during rainy seasons (K.L. Hunt, unpublished data; Weber and MacDaniels, 1969). Excessive sap flow in walnut and grape interferes with healing after grafting but can be reduced by making small cuts below the graft union or by withholding water from container-grown plants (Coggeshall and Beineke, 1997; Hartmann et al., 2011).

Huang et al. (1994) investigated graft compatibility of various chestnut species. Grafting success of various American (Castanea dentata Borkh.) or Japanese chestnut (C. crenata
Sieb. \& Zucc.) scions on 'AU-17' Chinese chestnut seedlings ranged from $6 \%$ to $93 \%$. For intraspecific grafts of Chinese chestnut, few unions were formed and $6 \%$ to $10 \%$ of the trees survived after 6 months when side veneer graft cuts were made through phloem fibers in rootstock stems. Because grafting success of chestnut has been problematic with commonly used nursery methods, experiments were conducted to: 1) examine the stem anatomy of Chinese chestnut rootstocks; 2) determine if the presence of secondary phloem fibers in the stem tissue is associated with unsuccessful graft unions; and 3) investigate the effect of rootstock stem and growing medium moisture content on whip and tongue grafting success.

\section{Materials and Methods}

Propagation of rootstocks. In Sept. 2006, nuts were harvested from 'AU-Cropper' and 'Qing' Chinese chestnut trees planted in a repository in 1996 at the Horticulture and Agroforestry Research Center (HARC), New Franklin, MO. Immediately after harvest, chestnuts were sealed in polyethylene bags and placed in cold storage at $5{ }^{\circ} \mathrm{C}$. On 15 Mar. 2007, these chestnuts were germinated in $35 \times 35 \times 13-\mathrm{cm}$ (depth) flats using a 8 pine bark:4 perlite: 2 sphagnum peatmoss: 1 vermiculite: 1 sand (v/v) medium amended with $2 \mathrm{~kg}$ Osmocote $13 \mathrm{~N}-5.7 \mathrm{P}-10.8 \mathrm{~K}, 1.5 \mathrm{~kg}$ Nitroform Blue Chip 38N-0P-0K (AgrEvo, Wilmington, DE), and $1.7 \mathrm{~kg}$ Micromax micronutrients (Scotts Co., Marysville, $\mathrm{OH}$ ) per cubed meter. Seedlings were then transplanted into 7.7-L polyethylene containers (PF800; Nursery Supply, Chambersburg, PA) on 1 May 2007 using the medium previously described. Potted seedlings were grown outdoors under natural conditions with supplemental irrigation for anatomical and budding experiments. On 25 Nov. 2007, potted seedlings were covered with a polyethylene foam blanket for winter protection. Seedlings were uncovered on 15 Mar. 2008 and remained in the nursery until anatomical studies were performed.

Anatomical studies. One year-old 'AUCropper' and 'Qing' seedlings with as many as 50 nodes were examined to determine the phyllotaxy of leaves on the stem. Next, $2 \mathrm{~mm}$ long segments of these seedlings ( 5 to $9 \mathrm{~mm}$ in diameter) at the third to the fifth internode above the growing medium surface (where rootstocks are often grafted) were placed in formalin-acetic acid-alcohol fixative. Later, segments were dehydrated in tertiary butyl alcohol series and infiltrated and embedded in paraplast (Sass, 1958). Serial sections $10 \mu \mathrm{m}$ in thickness were then microtomed and stained with toluidine blue or safranin $\mathrm{O}$ for examination using a stereomicroscope (Leica M205 FA; Leica Microsystems, Wetzlar, Germany). Toluidine blue was used to discriminate cell types in sections (Ruzin, 1999). For safranin O-stained sections, a dark red color indicated highly lignified cells.

Chip bud position on rootstocks. Rootstocks were propagated in Spring 2007 as 


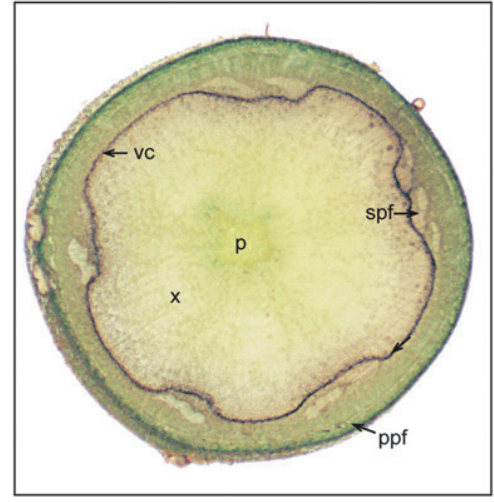

Fig. 1. Stem cross-section of a 1-year-old 'AUCropper' Chinese chestnut seedling rootstock. Note the pith (p), xylem (x), the lobed ring of vascular cambium (vc), clusters of secondary phloem fibers (spf), and a discontinuous ring of primary phloem fibers (ppf).

previously described and maintained outdoors in a container nursery under natural conditions with supplemental irrigation as needed. Irrigation was withheld for $10 \mathrm{~d}$ before grafting (with no rainfall). The day before grafting, rootstocks were cut in the middle of the terminal internode to ensure the absence of sap flow. Scion wood was collected immediately before grafting from 12-year-old 'Qing' and 'AU-Cropper' trees growing at HARC. To ascertain if the presence of secondary phloem fibers was associated with graft union failure, two chip buds were grafted onto each of 20 'Qing' and 'AU-Cropper' seedling rootstocks using the same cultivar/rootstock (i.e., 'Qing' buds on 'Qing' rootstock; 'AU-Cropper' buds on 'AU-Cropper' rootstock) on 19 Sept. 2007. Half of the rootstocks were chip-budded beside the third node above the growing medium surface and a second scion bud was placed below the fifth node. To confirm that bud position (upper vs. lower) did not affect grafting success, budding pattern was reversed on the remaining rootstocks with a chip bud placed below the third node above the growing medium surface and a second scion bud placed beside the fifth node. After budding, trees were maintained in a greenhouse $24^{\circ} \mathrm{C}$ day $/ 18^{\circ} \mathrm{C}$ night on a 12 -h cycle for 4 weeks before placing them in a container nursery area at HARC under 55\% shadecloth (DeWitt Group, Sikeston, MO). On 25 Nov., budded trees were covered with a polyethylene foam blanket for winter protection. On 12 Mar. 2008, containers of budded trees were uncovered and rootstock tissue above the upper graft union was removed. The number of scions in each position on rootstocks that produced growth was recorded on 20 Apr. Stem sections at both grafting positions from successful and unsuccessful unions were then obtained and prepared for light microscopy as previously described. Grafting success data for each cultivar and budding position were subjected to the GENMOD procedure of SAS (Version 9.2; SAS Institute, Cary, NC) with a logit link function for a binomial distribution $(P \leq 0.05)$.

Moisture content study. Because rainfall often occurs during the grafting season and

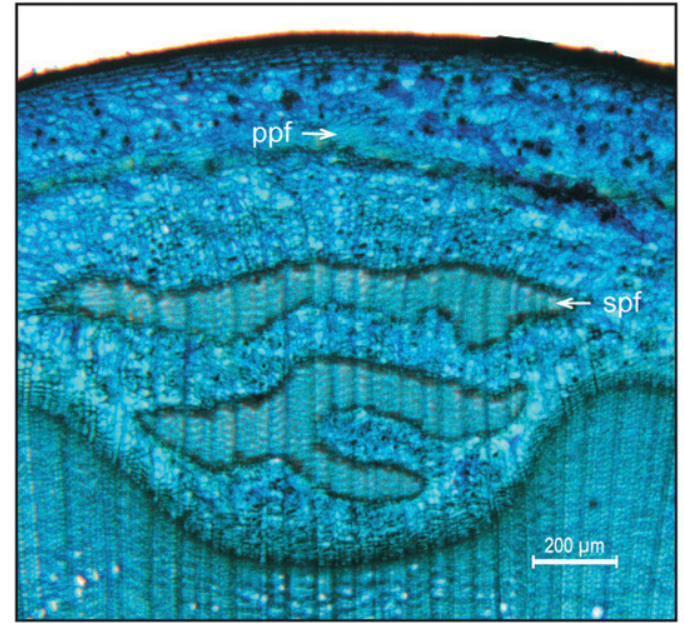

Fig. 2. Primary and secondary phloem fibers in a stem cross-section of 'AU-Cropper' Chinese chestnut seedling rootstock stained with toluidine blue. Note the discontinuous ring of primary phloem fibers (ppf) and the large clusters of secondary phloem fibers (spf).

results in sap flow from stems (i.e., stem bleeding), the effect of moisture content on graft union success was investigated. In Sept. 2008, 'AU-Cropper' chestnuts were collected from mature trees growing in the repository at HARC, germinated and grown for use as rootstocks in 2009, and overwintered in 7.7-L containers as previously described. Scion wood was collected from 15-year-old 'AUSuper' chestnut trees growing at HARC on 1 Mar. 2010, sealed in polyethylene bags, and stored at $5{ }^{\circ} \mathrm{C}$. On 23 Mar. 2010, potted rootstocks were placed in a greenhouse at $27{ }^{\circ} \mathrm{C}$ day $/ 21{ }^{\circ} \mathrm{C}$ night on a 12 -h cycle for forcing under natural light. Water was withheld until 3 Apr., when 20 containers each were uniformly irrigated with 0,800 , or $1600 \mathrm{~mL}$ of water. Two days later, all rootstocks were grafted with 'AU-Super' using the whip and tongue technique. To minimize any drying effects, one replication of rootstocks at all three moisture levels was grafted and sampled for moisture contents before proceeding to the next until 20 replications were completed. Rootstock stem tissue (directly above the cut for the graft) as well as a sample of the growing medium was collected for moisture content determinations at the time of grafting. A 2.5$\mathrm{cm}$-diameter core of growing medium was obtained from the entire profile of each container. Samples were then oven-dried at $65^{\circ} \mathrm{C}$ for $24 \mathrm{~h}$ and percent moisture content was calculated. Immediately after grafting, containers were maintained in a greenhouse 24 ${ }^{\circ} \mathrm{C}$ day/18 ${ }^{\circ} \mathrm{C}$ night on a 12 -h cycle for 4 weeks before placing them in a container nursery area at HARC under 55\% shadecloth. Moisture content data for the treatments were subjected to an analysis of variance using the PROC GLM procedure of SAS and means were separated by Fisher's protected least significant difference test, $P \leq$ 0.05 . Grafting success data were recorded on 3 Oct. 2010 and were subjected to the GENMOD procedure of SAS with a logit link function for a binomial distribution $(P \leq 0.05)$.

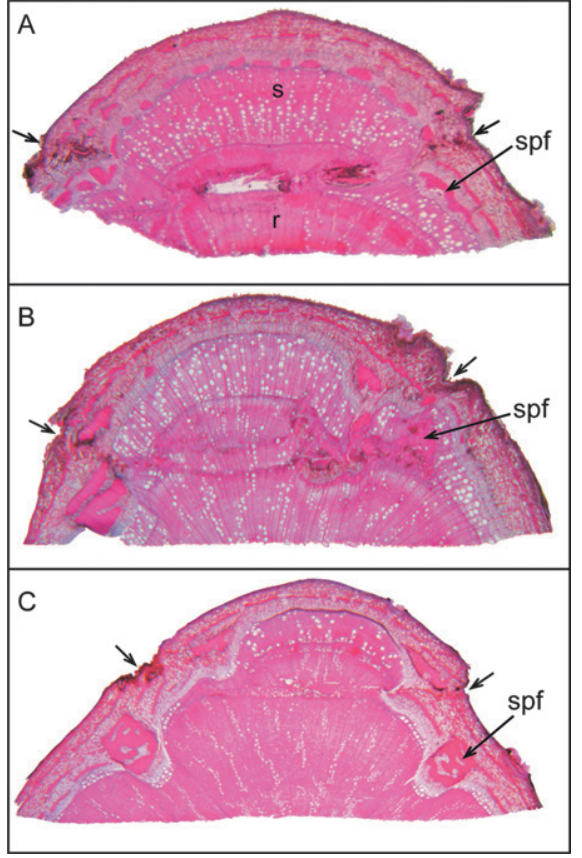

Fig. 3. Cross-sections of 'AU-Cropper' scions that were chip-budded onto 'AU-Cropper' seedling rootstocks at various positions. (A) A successful graft union in which a scion was budded below a rootstock node to avoid large clusters of secondary phloem fibers (spf) on a Chinese chestnut rootstock. (B) A successful graft union in which a scion was budded beside a rootstock node to disrupt a large cluster of secondary phloem fibers. (C) An unsuccessful graft union where 'AU-Cropper' scion bud and the rootstock cambia were misaligned when budded. Unlabeled arrows indicate the area where the scion bud was placed on the rootstock. Safranin O stained highly lignified cell walls dark red.

\section{Results}

Anatomical studies. Examination of 1year-old 'Qing' and 'AU-Cropper' seedlings revealed that these Chinese chestnuts have 2/ 5 phyllotaxy, in which five alternate leaves (or buds) are present in two revolutions around 
the stem with an $137.5^{\circ}$ angle between them (Levine, 2000). This arrangement of nodes is common on walnut, hickory, and oak trees. In cross-sections of 1-year-old Chinese chestnut stems, the vascular cambium was arranged in a regular five-lobed cylinder in which lobes were aligned with nodes (Fig. 1). Primary phloem fibers in a discontinuous ring were observed and secondary fibers were usually found clustered in the phloem tissue between the cambium lobes (Fig. 2).

Chip bud position on rootstocks. When two scions were grafted beside or below a node on 'AU-Cropper' and 'Qing' seedling rootstocks, grafting success was statistically similar for each cultivar and bud position. For 'AU-Cropper', 12 grafts were successful of which seven buds were chip-budded below a node on the rootstock and five buds were beside a node. For 'Qing', seven grafts were successful of which four buds were chipbudded below a rootstock node and three buds were beside a node. New scion growth produced from successful grafts on 20 Apr. averaged $35 \mathrm{~cm}$ for scions budded below a node and $34 \mathrm{~cm}$ for those budded beside a node. Also, graft union success rates of buds placed near the third and the fifth positions (e.g., upper vs. lower position) on rootstocks were statistically similar for each cultivar. Six scion buds placed in each position formed successful unions on 'AU-Cropper' rootstocks. On 'Qing' rootstocks, three scions budded near the fifth node and four placed near the third node formed unions. Photomicrographs of these rootstocks revealed that large secondary fiber clusters were avoided when scion buds were placed below a node, and some these grafts were successful (Fig. 3A). Scion buds placed beside a node interrupted clusters of secondary phloem fibers on the rootstock but did not always result in graft union failure (Fig. 3B). In failed grafts, cambial tissues of the scion and rootstock were misaligned and often the rootstock cambium produced a thin layer of xylem, but further differentiation did not occur (Fig. 3C).

Moisture content study. No sap flow was observed in any of the rootstocks before or after grafting. Also, stem moisture was similar among all treatments, ranging from 52.1\% to $53.6 \%$. Seedlings in containers that received 0,800 , or $1600 \mathrm{~mL}$ of water had growing medium moisture contents of $47.8 \%, 56.3 \%$, and $61.5 \%$, respectively. Graft union success was higher (75\%) for non-irrigated plants than those irrigated with $800 \mathrm{~mL}(25 \%)$ and 1600 $\mathrm{mL}(25 \%)$ of water.

\section{Discussion}

For successful union formation of budded woody tissues, rootstock and scion cambia must be aligned. When this occurs, parenchyma cells of the callus from both the scion and the rootstock divide near the necrotic layer to form a callus bridge and vascular continuity is subsequently established (Hartmann et al., 2011). Results of our study demonstrated that the five-lobed cylinder arrangement of the vascular cambium of Chinese chestnut makes the alignment of scion and rootstock cambia difficult. Although clusters of secondary phloem fibers were present between the lobes of the cambium or near this area in the stem, successful union formation occurred when grafting cuts were made through these rootstock fibers. Examination of unsuccessful unions revealed that scion and rootstock cambia were mismatched. In contrast to our results, Huang et al. (1994) reported the presence of only four "phloem fiber bundles" in Chinese chestnut stems. Also, high percentages of grafting failure $(96 \%$ to $100 \%)$ were attributed to disrupted cambial continuity purportedly caused by a proliferation of fiber tissue when side veneer cuts were made through phloem fibers.

Date of budding also influences grafting success. Although many other fruit and nut trees are budded by commercial nurserymen in July and August in the United States, grafting success was greater on 19 Sept. as compared with earlier dates (Warmund and Coggeshall, 2009). When chestnuts were budded too early (16 July or 15 Aug.), rootstock callus overgrew the scion bud, resulting in budding failure. Optimal dates for Chinese chestnut budding are likely site-dependent and may vary with rootstock. For example, the optimal budding date for 'Empire' apple on 'M.9' rootstock was 16 July in Washington, whereas the optimal budding date for the same scion/rootstock combination was 23 Sept. in Illinois (Warmund and Barritt, 1994).

Growing medium moisture content in container-grown rootstocks also affected whip and tongue grafting success in our study. Medium moisture content near $48 \%$ resulted in greater grafting success than when the moisture was above $56 \%$. In contrast, stem moisture contents, ranging from $52.1 \%$ to $53.6 \%$, had no apparent effect on grafting success. The reason why stem moisture was similar may be attributed to the relatively large volume of non-functional xylem tissue in rootstocks. These results demonstrate that even when sap flow from cut rootstocks is absent, growing medium moisture content influences graft union formation.

Although grafting techniques were not directly compared in this study, others reported varying results using different budding and grafting methods (Balta et al., 1993; Bazzigher et al., 1984; Huang et al., 1994; PereiraLorenzo and Fernanez-Lopez, 1997; Serdar and Soylu, 2005). In our work, 75\% grafting success was achieved using the whip and tongue technique when moisture was controlled in early spring. Although grafting containerized Chinese chestnut rootstocks may be more expensive than field grafting, moisture contents can be controlled under plastic outdoors or in a greenhouse. In contrast, success rates of field-grafting chestnut rootstocks in locations that have frequent rainfall may remain low as a result of excessive sap flow from stems.

In conclusion, this study demonstrated that a discontinuous ring of primary phloem fibers was present in 1-year-old Chinese chestnut seedling rootstocks as well as clusters of secondary phloem fibers. When grafting cuts were made through these secondary fibers, they did not prevent successful graft union formation when rootstock and scion cambial tissues were aligned. Misalignment of Chinese chestnut scion tissue with rootstock tissue occurred because of the non-uniform depth of the cambium at various positions around the stem, which was visible as a fivelobed ring of tissue in stem cross-sections. Controlled rootstock growing media moisture content was an additional important factor contributing to grafting success of intraspecific grafts of Chinese chestnut.

\section{Literature Cited}

Balta, F., T. Karadeniz, F.E. Tekintas, and S.M. Sen. 1993. Investigations on anatomical and histological development of the graft formation in chestnut (Castanea sativa L.). Proc. Intl. Congr. on Chestnut 4:231-234.

Bazzigher, G., K.P. Lawrenz, and F. Ritter. 1984. Propagating and growing chestnuts. Northern Nut Growers Assoc. Annu. Rpt. 75:119-137.

Coggeshall, M.V. and W.F. Beineke. 1997. Black walnut vegetative propagation: The challenge continues. USDA Forest Service Gen. Tech. Rpt. NC-191. p. 70-77.

Hartmann, H.T., D.E. Kester, F.T. Davies, Jr., and R.L. Geneve. 2011. Hartmann and Kester's plant propagation: Principles and practices. 8th Ed. Prentice Hall, Boston, MA.

Huang, J., J.D. Norton, G.E. Boyhan, and B.R. Abrahams. 1994. Graft compatibility among chestnut (Castanea) species. J. Amer. Soc. Hort. Sci. 119:1127-1132.

Hunt, K., M. Gold, W. Reid, and M. Warmund. 2009. Growing Chinese chestnuts in Missouri. Publ. AF-1003. Univ. of Missouri Center for Agroforestry, Columbia, MO.

Levine, C. 2000. Twig and leaf phyllotaxy. Conn. Bot. Soc. Newsletter. Vol. 28. Feb. 2012. $<$ http://www.ct-botanical-society.org/newsletter/ phyllotaxy.html>

MacDaniels, L.H. 1955. Stock-scion incompatibility in nut trees. Northern Nut Growers Annu. Rpt. 46:92-97.

McKay, J.W. and R.A. Jaynes. 1969. Chestnuts, p. 264-286. In: Jaynes, R.A. (ed.). Handbook of North American nut trees. W.F. Humphrey Press, Geneva, NY.

Pereira-Lorenzo and J. Fernanez-Lopez. 1997. Propagation chestnut cultivars by grafting: Methods, rootstocks and plant quality. J. Hort. Sci. 72:731739.

Reid, W. 2010. Propagating pecan and black walnut in Missouri. Publ. AF1003. Univ. of Missouri Center for Agroforestry, Columbia, MO.

Ruzin, S.E. 1999. Plant microtechnique and microscopy. Oxford Univ. Press, New York, NY.

Sass, J.E. 1958. Botanical microtechnique. 3rd Ed. Iowa State Univ. Press, Ames, IA.

Serdar, U. and A. Soylu. 2005. The effect of grafting time and methods on chestnut nursery tree production. Acta Hort. 693:187-194.

Warmund, M.R. 2011. Chinese chestnut (Castanea mollissima) as a niche crop in the central region of the United States. HortScience 46:345-347.

Warmund, M.R. and B.H. Barritt. 1994. Survival and growth of 'Empire' apple chip budded onto Mark or M.9 rootstock. Fruit Var. J. 48:245-250.

Warmund, M.R. and M.V. Coggeshall. 2009. Chip budding of 'AU-Super' Chinese chestnut scions on AU-Cropper and Qing seedling rootstocks. Acta Hort. 844:115-118.

Weber, G.C. and L.H. MacDaniels. 1969. Propagation, p. 29. In: Jaynes, R.A. (ed.). Handbook of North American nut trees. Northern Nut Growers Assn., Knoxville, TN. 